HEJ (Home Economics Journal). Vol. 1, No. 1. May 2017, 29-37

ISSN 2579-4272 (printed), ISSN 2579-4280 (online)

\title{
PENERAPAN KESEHATAN DAN KESELAMATAN KERJA (K3) PADA LABORATORIUM TATA RIAS DAN KECANTIKAN
}

\author{
Asi Tritanti ${ }^{1}$ dan Ika Pranita Siregar ${ }^{2}$ \\ 1,2 Pendidikan Teknik Boga dan Busana \\ ${ }^{1,2}$ Fakultas Teknik Universitas Negeri Yogyakarta \\ Email: asi_tritanti@uny.ac.id
}

\begin{abstract}
ABSTRAK
Penelitian bertujuan: (1) mengetahui penerapan K3 di prodi tata rias untuk diri sendiri, alat dan bahan praktik, serta area kerja, (2) membuat Standar Operasional Prosedur (SOP) yang sesuai K3 untuk kegiatan praktik (2) tata kecantikan kulit, (3) tata kecantikan rambut, dan (4) tata rias pengantin. Penelitian ini adalah penelitian deskriptif kualitatif model interaktif Miles dan Huberman. Subjek penelitian adalah mahasiswa prodi tata rias semester genap 2015/2016 dan semester ganjil 2016/2017, dosen dan laboran Prodi Tata Rias. Data dikumpulkan dengan lembar observasi, kuisioner dan wawancara. Teknik analisis data yang digunakan adalah deskriptif kualitatif. . Hasil penelitian menunjukkan: (1) Kesehatan dan Keselamatan Kerja (K3) di prodi tata rias pada diri sendiri, alat dan bahan praktik, serta area kerja praktik sudah diterapkan. Mahasiswa, laboran dan dosen pengampu memiliki komitmen melakukan K3, memiliki pengetahuan dasar K3, dan bersedia menerapkan K3 sesuai dengan SOP yang berlaku, Standar Operasional Prosedur yang sesuai prinsip K3 untuk (2) bidang keahlian tata kecantikan kulit dibuat dengan memperhatikan prinsip dasar dan kompetensi tata kecantikan kulit, (3) tata kecantikan rambut dibuat dengan memperhatikan prinsip dasar dan kompetensi tata kecantikan rambut, dan (4) praktik tata rias pengantin dibuat dengan memperhatikan konsep dasar dan jenis tata rias pengantin dengan kompetensi rias pengantin Indonesia, pengantin Barat, dan Pengantin Muslim
\end{abstract}

Kata kunci: penerapan K3, SOP, praktik Tata Rias PENDAHULUAN

Tata rias dan kecantikan adalah salah satu Program Studi (Prodi) di Jurusan Pendidikan Teknik Boga dan Busana (PTBB), dan berada dalam naungan Fakultas. Prodi ini merupakan program studi jenjang Diploma 3, yang menghasilkan lulusan siap pakai yang mandiri, bernurani dan cendekia sebagai tenaga kerja dan entepreneur yang kompeten, professional, dan kompetitif, baik dalam skala regional, nasional, maupun internasional di berbagai bidang keahlian tata rias dan kecantikan. Bidang keahlian tersebut antara lain adalah make up artist, beauty therapist, hair stylist, trainer/ instruktur tata rias, entepreneur di bidang salon kecantikan, rias pengantin, wedding organizer dan teknisi laboratorium Tata Rias. Capaian pembelajaran dari masing-masing bidang keahlian tata rias dapat tercapai jika para mahasiswa/lulusan memiliki kompetensi pelaksanaan K3.
Kesehatan dan Keselamatan Kerja (K3) tidak bisa dipandang sebelah mata dalam bidang pekerjaan apapun, karena sangat terkait dengan sumber daya manusia sebagai pelaku kerja. Terlebih lagi pada bidang kerja tata rias yang merupakan salah satu bidang pelayanan jasa. Apabila kegiatan yang dilakukan dalam bidang pelayanan jasa ini tidak dilakukan sesuai dengan prosedur yang terstandar, maka dapat menimbukan gangguan kesehatan dan keselamatan baik bagi pekerja, maupun bagi klien/pemanfaat jasa.

Penyebab terjadinya gangguan kesehatan dan keselamatan kerja, yang disebabkan oleh faktor manusia (mahasiswa) adalah perilaku mahasiswa dalam melakukan praktik kerja, kompetensi yang belum dikuasai dengan baik oleh mahasiswa, prosedur kerja yang tidak diikuti dengan benar, dan kurangnya pengalaman.Faktor-faktor yang dapat menjadi sumber gangguan kesehatan dan keselamatan kerja adalah kelelahan fisik 
berlebihan pada mahasiswa, peralatan dan bahan-bahan yang digunakan untuk praktik tidak memenuhi syarat/tidak layak pakai, selain itu peralatan yang tidak dikontrol penggunaannya, seperti melebihi batas waktu pemakaian sehingga peralatan over heat. Peralatan yang digunakan tidak sebagaimana mestinya, seperti digunakan sebagai peralatan pengganti atau digunakan tidak sesuai dengan kegunaannya.

Faktor pemicu gangguan kesehatan dan keselamatan kerja yang disebabkan oleh bahan-bahan kosmetik yaitu bahan kimia Potensi yang mungkin timbul dari penggunaan bahan kosmetik ini antara lain: 1) penyimpanan yang tidak tepat, seperti suhu ruang terlalu panas, tempat penyimpanan tidak memiliki ventilasi yang cukup, penataan kosmetik terlalu rapat dan padat; 2) penggunaan kosmetik yang salah prosedur, seperti pencampuran beberapa kosmetik tidak sesuai perbandingannya sehingga dapat menimbulkan reaksi kimia yang merusak, penggunaan yang tidak sesuai kebutuhan, seperti kosmetik perawatan untuk kulit kering digunakan untuk merawat kulit berminyak, penggunaan kosmetik yang berlebihan, serta tidak menerapkan uji sensitivitas kulit terlebih dulu; 3) tidak memperhatikan batas kadaluwarsa kosmetik sehingga akan menimbulkan kerugian baik dari segi kesehatan juga keselamatan kerja, 4) sensitivitas pengguna kosmetik,sehingga dapat menimbulkan gangguan kesehatan dan ketidaknyamanan, seperti beberapa jenis kosmetik memiliki bau menyengat yang tidak sedap, dapat menimbulkan rasa gatal bagi beberapa orang, dan lain sebagainya.

Faktor dari area kerja yang dapat menjadi sumber gangguan kesehatan dan kecelakaan kerja antara lain: lantai licin jika terkena air, sementara pada sebagian besar praktik kerja membutuhkan air dalam proses pelaksanaannya, sumber arus listrik yang kelebihan beban, ruang praktik yang kurang memadai dengan jumlah penggunanya sehingga mahasiswa yang melakukan praktik kerja kurang leluasa untuk bergerak. Penggunaan kaca/ cermin harus diperhatikan keamanannya agar tidak menimbulkan ganguuan yang tidak diinginkan.

Berdasarkan hasil pengamatan, temuan, dan kondisi yang ada di Laboratorium Tata Rias, dapat dilihat bahwa penerapan keselamatan dan kesehatan kerja di laboratorium tata rias belum maksimal sehingga persoalan implementasi dan penerapan K3 menjadi sangat penting.

Berdasarkan hal tersebut maka penelitian ini dilakukan untuk (1) mengetahui penerapan K3 di lingkungan prodi tata rias baik penerapan K3 pada diri sendiri, alat dan bahan praktik, serta area kerja praktik, membuat SOP yang sesuai dengan prinsip K3 untuk kegiatan praktik (2) tata kecantikan kulit, (3) tata kecantikan rambut, (4) tata rias pengantin.

\section{METODE}

Penelitian ini adalah penelitian khususnya deskriptif kualitatif. Pada hakekatnya penelitian deskriptif kualitatif adalah salah satu metode meneliti status sekelompok manusia, suatu objek dengan tujuan membuat deskriptif, gambaran atau lukisan secara sistematis, faktual dan akurat mengenai fakta-fakta atau fenomena yang diselidiki. Prosedur penelitian yang digunakan mengacu pada model interaktif Miles dan Huberman [6]. Hal ini bertujuan untuk memperoleh gambaran data dan fakta yang nyata, sehingga dapat membuat panduan SOP praktik yang tepat untuk 3 bidang keahlian kecantikan 


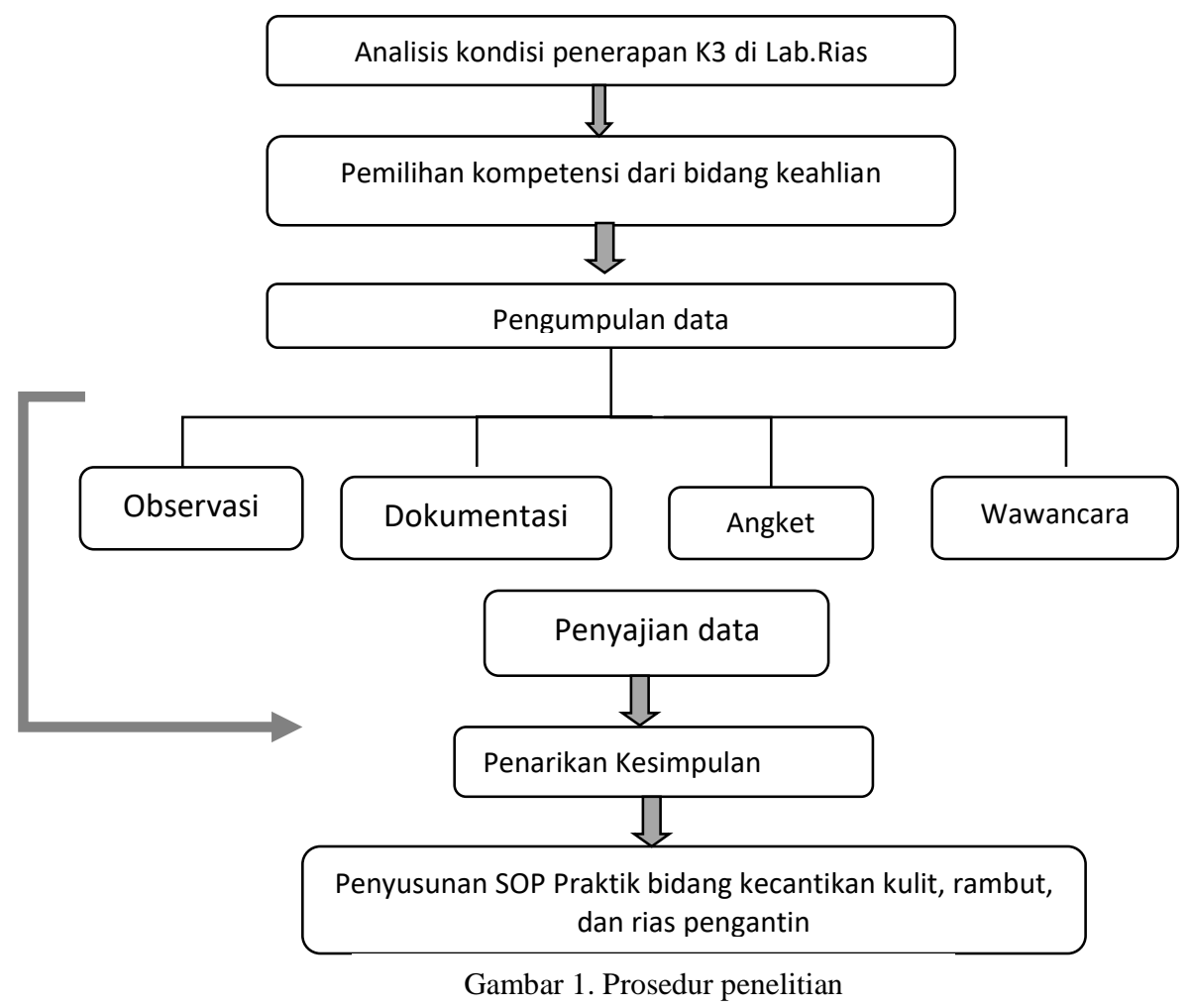

Penelitian dilakukan di Prodi Tata Rias Fakultas Teknik (FT) UNY dan dilaksanakan pada bulan Mei sampai September 2016. Subyek penelitian ini adalah mahasiswa prodi tata rias semester genap 2015/2016 dan semester ganjil 2016/2017, dosen dan laboran Prodi Tata Rias.

Instrumen penelitian adalah lembar observasi, lembar kuesioner penerapan K3, panduan wawancara, dokumentasi,dan panduan standar operasional prosedur peralatan kecantikan.

Pengumpulan data dilakukan dengan cara: 1) Observasi (Pengamatan) dilakukan dengan cara mengamati langsung objek yang diteliti yaitu mahasiswa, laboran dan dosen pengampu praktik selama kegiatan kuliah praktik berlangsung di laboratorium Tata Rias meliputi pelindung diri, perawatan badan, alat, bahan dan area kerja, sumber-sumber bahaya yang ada selama praktikum, dan gangguan kesehatan dan kecelakaan akibat kerja yang mungkin terjadi di laboratorium, kepada dosen dan mahasiswa prodi Tata Rias untuk mendapatkan keterangan-keterangan lisan berkaitan dengan pengetahuan dan penerapan K3 dalam kegiatan praktik di laboratorium tata rias. Hasil wawancara ini berguna untuk melengkapi data yang diperoleh melalui observasi, 3) Dokumentasi, digunakan untuk mengetahui pedoman Sistem K3 dan data-data statistik tentang kecelakaan kerja, dan gangguan kesehatan akibat kerja khususnya di laboratorium tata rias. Selain itu dokumentasi ini juga merekam gambar-gambar selama kegiatan praktik yang tidak sesuai dengan prinsip K3, 4) Angket, digunakan untuk mencari data mengenai hal-hal yang dirasakan dan dialami sendiri oleh subjek penelitian berkaitan dengan penerapan K3 dalam kegiatan di laboratorium tata rias.

Metode analisis yang digunakan adalah analisis data menurut Miles dan Huberman [6]. 


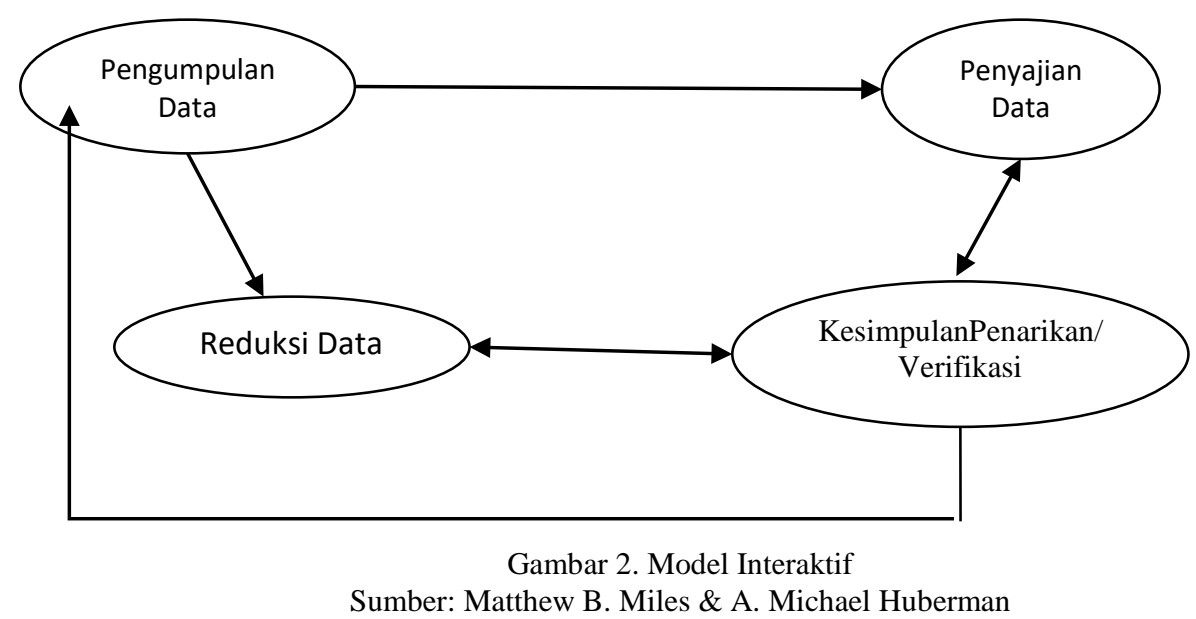

\section{HASIL DAN PEMBAHASAN}

\section{Hasil}

Penerapan K3 pada Laboratorium Tata Rias dapat diketahui dari tingkat pengetahuan/pemahaman dosen, laboran, dan mahasiswa serta perilaku mereka terhadap penerapan K3 dalam praktik. Penerapan K3 pada dosen dan laboran meliputi aspek komitmen, pengetahuan, dan pelaksanaan K3. Sementara penerapan K3 pada mahasiswa meliputi pengetahuan dan perilaku penerapan K3 pada aspek lingkungan kerja, hygiene diri sendiri, alat kerja, bahan praktikum (kimia/kosmetik), model, dan ergonomi.

\section{Deskripsi Komitmen, Tingkat Pengetahuan, dan Pelaksanaan K3 Dosen dan Laboran}

Komitmen dosen dan laboran terhadap penerapan K3 di lingkungan kerja fakultas sangat baik, hal ini dapat dilihat dari ada $100 \%$ dosen dan laboran mempunyai komitmen teguh terhadap pelaksanaan K3 di lingkungan fakultas.

Tingkat pengetahuan dosen dan laboran terhadap penerapan K3 di lingkungan fakultas dapat dikatakan baik, hal ini dapat dilihat dari ada $62 \%$ dosen dan laboran sudah tahu dan $18 \%$ dosen dan laboran sudah sangat tahu, dan 18\% tidak tahu. Dari data tersebut maka tingkat pengetahuan dosen dan laboran terhadap penerapan K3 di lingkungan faklutas sebesar $62 \%$ perlu ditingkatkan menjadi lebih sangat tahu terhadap pentingnya penerapan K3 di lingkungan fakultas terutama di laboratorium Tata Rias

Tingkat pelaksanan K3 oleh dosen dan laboran di lingkungan kerja sudah sangat baik, hal ini dapat dilihat hampir 100\% dosen sangat setuju terhadap pelaksanaan K3 di lingkungan kerja yaitu 95\% dan hanya 5\% dosen dan laboran sangat tidak setuju terhadap pelaksanaan K3. Dari persentase ini dapat dilihat bahwa 5\% dosen dan laboran yang tidak setuju dengan pelaksanaan K3 maka perlu ditinjau ulang, perlu ditingkatkan pengetahuan sehingga dapat menumbuhkan kesadaran pelaksanaan K3 sangat penting untuk dilakukan.

\section{Pengetahuan Penerapan K3 Mahasiswa pada Lingkungan Kerja, Bahan Kimia/Kosmetik, Alat Kerja, Ergonomi}

Tingkat pengetahuan mahasiswa pada penerapan K3 di lingkungan kerja sudah sangat baik, hal ini dapat dilihat dari ada $61 \%$ mahasiswa sudah tahu dan 35\% mahasiswa sudah sangat tahu, dan hanya $4 \%$ tidak tahu.

Tingkat pengetahuan penerapan K3 pada bahan kimia/kosmetik oleh mahasiswa dapat dikategorikan sangat baik karena ada $66 \%$ mahasiswa sudah tahu, dan 30\% sudah sangat tahu, dan hanya sedikit yang belum tahu sekitar $4 \%$.

Tingkat pengetahuan penerapan K3 pada alat kerja oleh mahasiswa dapat dikategorikan sangat baik karena ada sebesar 
73\% mahasiswa mengetahui penerapan K3 pada alat kerja, 23\% mahasiswa sangat tahu dan hanya $4 \%$ yang belum mengetahui penerapan K3 pada alat kerja.

Tingkat pengetahuan penerapan K3 pada ergonomi oleh mahasiswa dapat dikategorikan sangat baik karena ada $80 \%$ mahasiswa sudah mengetahui penerapan K3 pada ergonomi dan $13 \%$ yang belum mengetahui penerapan K3 pada ergonomi oleh mahasiswa, dan sisanya hanya $8 \%$ sudah sangat tahu penerapan K3 pada ergonomi.

\section{Sikap/Perilaku Penerapan K3 Mahasiswa pada Hygiene Diri Sendiri, Bahan Kimia/Kosmetik, Alat Kerja, Model, Ergonomi}

Sikap/perilaku penerapan K3 pada Hygiene diri sendiri oleh mahasiswa dapat dikategorikan sangat baik karena ada 87\% mahasiswa menerapkan K3 pada Hygiene Diri Sendiri dan hanya 13\% mahasiswa yang belum menerapkan K3 pada hygiene diri sendiri.

Sikap/perilaku penerapan K3 pada bahan kimia/kosmetik oleh mahasiswa dapat dikategorikan sangat baik karena ada 95\% mahasiswa sudah menerapkan K3 pada bahan kimia/kosmetik (mulai dari persiapan, penggunaan, dan pasca penggunaan bahan kimia/kosmetik) dan hanya 5\% yang belum menerapkan K3 pada bahan kimia/kosmetik

Sikap/perilaku penerapan K3 pada alat kerja oleh mahasiswa dapat dikategorikan sangat baik karena ada hampir 100\% yaitu 96\% mahasiswa sudah menerapkan K3 pada alat kerja dan hanya $4 \%$ yang belum.

Sikap/perilaku penerapan K3 pada model oleh mahasiswa dapat dikategorikan sangat baik karena ada 97\% mahasiswa sudah menerapkan K3 pada model dan hanya sedikit sekali yaitu 3\% yang belum.

Sikap/perilaku penerapan K3 pada ergonomi oleh mahasiswa dapat dikategorikan sangat baik karena ada hampir 100\% yaitu 97\% mahasiswa sudah menerapkan K3 pada ergonomi dan hanya 3\% mahasiswa yang belum menerapkan K3 pada ergonomi.

\section{Pembahasan}

Penerapan K3 pada Laboratorium Tata Rias berdasarkan hasil angket menunjukan hasil yang baik, artinya dosen, laboran, dan mahasiswa memahami dan mengetahui bagaimana menerapkan K3 dalam kegiatan praktik. Hasil wawancara yang dilakukan pada mahasiswa juga menunjukan hasil yang baik, yaitu mahasiswa sudah memahami dengan baik pengetahuan dan penerapan K3 saat melakukan praktik di lab.tata rias. Sementara itu hasil observasi dan dokumentasi merekam kondisi yang relatif berbeda dengan hasil angket dan wawancara. Pada kegiatan observasi, ditemukan bahwa prilaku subjek penelitian terhadap penerapan K3 kurang menunjukan komitmen yang baik seperti dalam Tabel 2.

Tabel 2. Hasil Observasi Penerapan K3 Pada Laboratorium Tata Rias dan Kecantikan

\begin{tabular}{|c|c|c|c|c|}
\hline \multirow[b]{2}{*}{$\begin{array}{l}\text { Ruang lingkup } \\
\text { observasi }\end{array}$} & \multirow[b]{2}{*}{ Indikator observasi } & \multicolumn{3}{|c|}{ Bidang keahlian } \\
\hline & & $\begin{array}{c}\text { Tata Kecantikan } \\
\text { Kulit* } \\
\end{array}$ & $\begin{array}{c}\text { Tata Kecantikan } \\
\text { Rambut** }\end{array}$ & $\begin{array}{c}\text { Tata Rias } \\
\text { Pengantin*** }\end{array}$ \\
\hline \multirow{3}{*}{$\begin{array}{l}\text { 1. Kebersihan } \\
\text { rambut dan } \\
\text { kepala }\end{array}$} & $\begin{array}{ll}\text { 1.1. Rambut /jilbab dalam kondisi bersih } \\
\text { dan wangi }\end{array}$ & Ya & Ya & Ya \\
\hline & $\begin{array}{ll}\text { 1.2. } & \text { Rambut/jilbab ditata dengan baik dan } \\
\text { rapi }\end{array}$ & Ya & Sebagian & Ya \\
\hline & $\begin{array}{l}\text { 1.3. Gangguan kesehatan rambut dan kulit } \\
\text { kepala yang menular }\end{array}$ & Tidak & Tidak & Tidak \\
\hline \multirow{3}{*}{$\begin{array}{l}\text { 2. Kebersihan } \\
\text { tangan dan } \\
\text { kuku }\end{array}$} & 2.1. Tangan, kaki, dan kuku yang bersih & Ya & Ya & Ya \\
\hline & $\begin{array}{l}\text { 2.2. Kuku tangan tidak melebihi } 4 \mathrm{~mm} \text {, } \\
\text { tidak kering dan kusam }\end{array}$ & Ya & Ya & Ya \\
\hline & $\begin{array}{l}\text { 2.3. } \begin{array}{l}\text { Mencuci tangan dengan sabun } \\
\text { sebelum dan sesudah kontak dengan } \\
\text { melakukan pekerjaan }\end{array} \\
\end{array}$ & Sebagian & Sebagian & Sebagian \\
\hline
\end{tabular}




\begin{tabular}{|c|c|c|c|c|}
\hline \multirow[b]{2}{*}{$\begin{array}{l}\text { Ruang lingkup } \\
\text { observasi }\end{array}$} & \multirow[b]{2}{*}{ Indikator observasi } & \multicolumn{3}{|c|}{ Bidang keahlian } \\
\hline & & $\begin{array}{c}\text { Tata Kecantikan } \\
\text { Kulit* } \\
\end{array}$ & $\begin{array}{c}\text { Tata Kecantikan } \\
\text { Rambut** } \\
\end{array}$ & $\begin{array}{c}\text { Tata Rias } \\
\text { Pengantin*** }\end{array}$ \\
\hline \multirow{3}{*}{$\begin{array}{l}\text { 3. Kebersihan } \\
\text { badan }\end{array}$} & 3.1. Badan bersih dan segar & Ya & Ya & Ya \\
\hline & 3.2. Menggunakan deodorant & Sebagian & Sebagian & Sebagian \\
\hline & 3.3. $\quad$ Terdapat penyakit kulit yang menular & Tidak & Tidak & Tidak \\
\hline \multirow{3}{*}{$\begin{array}{l}\text { 4. Kebersihan } \\
\text { gigi dan } \\
\text { mulut } \\
\end{array}$} & 4.1. Gigi yang bersih & $\mathrm{Ya}$ & Ya & Ya \\
\hline & 4.2. Mulut segar dan tidak berbau & Sebagian & Sebagian & Sebagian \\
\hline & 4.3. Makan dan minum selama praktik & Tidak & Tidak & Tidak \\
\hline \multirow{8}{*}{$\begin{array}{ll}\text { 5. } & \text { Kebersihan } \\
\text { pakaian dan } \\
\text { alat } \\
\text { pelindung } \\
\text { diri } \\
\end{array}$} & 5.1. Pakaian bersih dan segar, tidak berbau & Sebagian & Sebagian & Ya \\
\hline & 5.2. $\quad$ Penggunaan jas praktik & Ya & $\mathrm{Ya}$ & Ya \\
\hline & 5.3. Pakaian sopan dan tidak ketat & Ya & $\mathrm{Ya}$ & Ya \\
\hline & 5.4. $\quad$ Penggunaan sepatu datar dan tertutup & Sebagian & $\mathrm{Ya}$ & Sebagian \\
\hline & 5.5. $\quad$ Penggunaan perhiasan & Tidak & Sebagian & Sebagian \\
\hline & $\begin{array}{ll}\text { 5.6. Penggunaan masker penutup mulut } \\
\text { dan hidung }\end{array}$ & Sebagian & Sebagian & Sebagian \\
\hline & 5.7. $\quad$ Penggunaan sarung tangan karet & Sebagian & Tidak & Tidak \\
\hline & $\begin{array}{l}\text { 5.8. Penggunaan lenan (handuk, seprai, } \\
\text { penutup dada) yang bersih }\end{array}$ & Sebagian & Sebagian & Sebagian \\
\hline \multirow{7}{*}{ 6. $\quad$ Ergonomi } & 6.1. Posisi tubuh berdiri sempurna & Sebagian & Sebagian & Tidak \\
\hline & 6.2. $\quad$ Posisi tubuh membungkuk & Sebagian & Sebagian & sebagian \\
\hline & 6.3. Posisi tubuh duduk di atas kursi & Tidak & Tidak & Tidak \\
\hline & 6.4. $\quad$ Posisi tubuh duduk di alas tikar & Tidak & Tidak & Ya \\
\hline & 6.5. $\quad$ Posisi tubuh berjongkok & Sebagian & Sebagian & sebagian \\
\hline & $\begin{array}{l}\text { 6.6. Posisi tubuh mengangkat benda berat } \\
\text { (beauty case, kursi, kaca rias, bed } \\
\text { facial) }\end{array}$ & Ya & Ya & Ya \\
\hline & $\begin{array}{l}\text { 6.7. Posisi tubuh menggeser benda berat } \\
\text { (meja rias, vapozone, climazone, } \\
\text { robotic ozon) }\end{array}$ & Ya & Ya & Ya \\
\hline \multirow[t]{5}{*}{ 7. $\quad$ Mekanik } & $\begin{array}{l}\text { 7.1. Penggunaan gunting (gunting pangkas, } \\
\text { penipis, gunting biasa) dengan benar }\end{array}$ & & Sebagian & \\
\hline & 7.2. $\quad$ Penggunaan kuas dengan benar & Ya & $\mathrm{Ya}$ & $\mathrm{Ya}$ \\
\hline & 7.3. Penggunaan razor dengan benar & & Sebagian & \\
\hline & 7.4. Penggunaan pisau dengan benar & Sebagian & & \\
\hline & 7.5. Penggunaan jepit rambut dengan benar & & Sebagian & sebagian \\
\hline \multirow[t]{6}{*}{$\begin{array}{ll}\text { 8. } & \text { Elektrikal }\end{array}$} & $\begin{array}{l}\text { 8.1. Menyalakan dan mematikan sumber } \\
\text { arus listrik dengan benar }\end{array}$ & Ya & Ya & Sebagian \\
\hline & 8.2. Memasang alat ke sumber listrik & Ya & Ya & $\mathrm{Ya}$ \\
\hline & $\begin{array}{lllll}\text { 8.3. } & \begin{array}{l}\text { Mengecek kondisi alat sebelum } \\
\text { digunakan }\end{array} & & \\
\end{array}$ & Ya & Sebagian & Sebagian \\
\hline & $\begin{array}{ll}\text { 8.4. } & \begin{array}{l}\text { Menyalakan alat } \\
\text { digunakan }\end{array} \\
\end{array}$ & Ya & Ya & Ya \\
\hline & 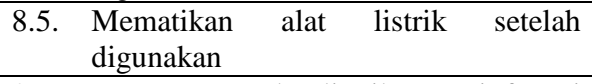 & Ya & Sebagian & sebagian \\
\hline & $\begin{array}{ll}\text { 8.6. Penggunaan alat listrik sesuai fungsi } \\
\text { dan kebutuhan }\end{array}$ & Ya & Ya & Ya \\
\hline \multirow{8}{*}{$\begin{array}{l}\text { 9. } \begin{array}{l}\text { Pengelolaan } \\
\text { kosmetik }\end{array} \\
\text { kosm }\end{array}$} & 9.1. Membaca label kosmetik & Sebagian & Sebagian & sebagian \\
\hline & $\begin{array}{ll}\text { 9.2. } & \begin{array}{l}\text { Mencermati etiket } \\
\text { kosmetik }\end{array} \\
\end{array}$ & Sebagian & Sebagian & sebagian \\
\hline & 9.3. $\quad$ Mengecek masa kadaluarsa kosmetik & $\mathrm{Ya}$ & $\mathrm{Ya}$ & $\mathrm{Ya}$ \\
\hline & $\begin{array}{llrr}\text { 9.4. } & \begin{array}{l}\text { Mencermati sifat } \\
\text { sebelum digunakan }\end{array} & \text { fisik } & \text { kosmetik } \\
\end{array}$ & Ya & Ya & Tidak \\
\hline & $\begin{array}{ll}\text { 9.5. } & \text { Mencermati bentuk dan aroma/bau } \\
\text { kosmetik sebelum digunakan }\end{array}$ & Tidak & Tidak & Tidak \\
\hline & 9.6. $\quad$ Mengambil kosmetik sesuai kebutuhan & Sebagian & Sebagian & Sebagian \\
\hline & 9.7. Mengecek kebersihan wadah kosmetik & $\mathrm{Ya}$ & Sebagian & Sebagian \\
\hline & 9.8. Menuangkan kosmetik dengan hati- & Ya & Ya & Ya \\
\hline
\end{tabular}




\begin{tabular}{|c|c|c|c|c|}
\hline \multirow{2}{*}{$\begin{array}{l}\text { Ruang lingkup } \\
\text { observasi }\end{array}$} & \multirow[b]{2}{*}{ Indikator observasi } & \multicolumn{3}{|c|}{ Bidang keahlian } \\
\hline & & $\begin{array}{c}\text { Tata Kecantikan } \\
\text { Kulit* }\end{array}$ & $\begin{array}{l}\text { Tata Kecantikan } \\
\text { Rambut** }\end{array}$ & $\begin{array}{c}\text { Tata Rias } \\
\text { Pengantin*** }\end{array}$ \\
\hline \multicolumn{5}{|c|}{$\begin{array}{l}\text { hati ke wadah kosmetik dan menutup } \\
\text { wadah dengan benar }\end{array}$} \\
\hline & $\begin{array}{ll}\text { 9.9. } & \text { Menggunakan kosmetik sesuai fungsi } \\
\text { dan kegunaannya }\end{array}$ & Ya & Ya & Ya \\
\hline & $\begin{array}{ll}\text { 9.10. } & \text { Membuang sisa penggunaan bahan } \\
\text { kosmetik dengan benar }\end{array}$ & Ya & Ya & Ya \\
\hline \multirow{6}{*}{$\begin{array}{l}\text { 10. Sanitasi dan } \\
\text { hygiene pada } \\
\text { alat dan area } \\
\text { kerja }\end{array}$} & $\begin{array}{llll}\text { 10.1. } & \begin{array}{l}\text { Menyiapkan tempat } \\
\text { tertutup }\end{array} & \text { sampah } \\
\end{array}$ & Ya & Sebagian & sebagian \\
\hline & 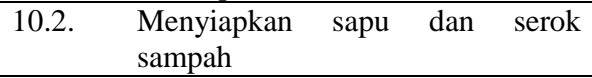 & Tidak & Tidak & Tidak \\
\hline & Mengalasi meja kerja dengan lenan & Sebagian & Sebagian & Sebagian \\
\hline & $\begin{array}{llll}\text { 10.4. } & \begin{array}{l}\text { Mensterilkan alat logam dan } \\
\text { handuk ke dalam sterilisator } \\
\text { cabinet }\end{array} & & \\
\end{array}$ & Ya & Tidak & Tidak \\
\hline & Mengecek kebersihan & Sebagian & Sebagian & \\
\hline & Mengecek suhu air & Ya & Ya & \\
\hline \multicolumn{5}{|c|}{$\begin{array}{lll}\text { Hasil yang menunjukan “ya” } & \text { menggunakan masker penutup mulut dan } \\
\text { bermakna penerapan K3 sudah dilakukan } & \text { hidung saat melakukan perawatan dan merias } \\
\text { dengan baik, hasil yang menunjukan } & \text { wajah, serta menggunakan lenan yang kurang } \\
\text { "sebagian” bermakna penerapan K3 dilakukan } & \text { bersih. }\end{array}$} \\
\hline
\end{tabular}

oleh sebagian besar komunitas di dalam kelas, baik mahasiswa, laboran dan dosen pengampu. Hasil yang menunjukan "tidak" bermakna bahwa penerapan K3 benar-benar tidak dilaksanakan. Berdasarkan hasil observasi tersebut dapat disimpulkan bahwa prilaku subjek penelitian terhadap penerapan K3 kurang menunjukan komitmen yang baik, karena saat melakukan praktik adalah saat dimana mahasiswa menjadi diri sendiri dan melakukan kegiatan praktik secara sadar dan terencana. Mahasiswa mengetahui dan memahami prinsip dan pengetahuan dasar K3 tetapi tidak menerapkan dalam kegiatan praktik.

Perilaku yang kurang menunjukkan komitmen untuk menerapkan K3 sesuai standar sangat berpotensi menimbulkan gangguan kesehatan dan kecelakaan kerja. Pada laboratorium rias, 90\% kegiatan praktik melibatkan model. Berdasarkan hasil observasi Tabel 2 diatas, pada ruang lingkup observasi personal hygiene ditemukan bahwa tidak semua mahasiswa mencuci tangan dengan sabun dan membilasnya dengan air sebelum melakukan praktik. Dari segi kebersihan tubuh, sebagian mahasiswa tidak menggunakan deodorant atau memiliki aroma tubuh kurang sedap sehingga mengganggu orang yang berada di dekatnya. Selain itu saat melakukan praktik, masih ada yang tidak menggunakan alas kaki tertutup dan hak datar, serta masih ada yang menggunakan perhiasan pada saat memegang klien. Tidak
Potensi gangguan kesehatan dan kecelakaan kerja yang dapat timbul dari kondisi tersebut di atas adalah iritasi, alergi dan penularan penyakit dari dan atau klien ke model akibat dari tidak mencuci tangan, tidak menggunakan lenan yang bersih, dan menggunakan perhiasan apabila terkena zat kimia tertentu yang ada dalam kosmetik. Potensi terpeleset atau bahkan terkilir saat bekerja mungkin timbul akibat dari penggunaan sepatu bersol tinggi (bukan hak datar).

Pada observasi ergonomi, sebagian besar mahasiswa pada saat melakukan praktik tidak menyamankan dirinya terlebih dahulu, dengan cara mengatur jarak antara barang yang ada disekitar saat bekerja, mengatur jarak antara sesama mahasiswa dan model, mengatur posisi tubuh yang baik dan benar saat mengangkat dan menggeser benda berat dapat menimbulkan gangguan kesehatan seperti tubuh pegal, terkilir dan cedera otot. Hal ini disebabkan karena beberapa faktor antara lain luas ruangan praktik kurang memadai dengan jumlah mahasiswa dan model, sehingga tidak tersedia area kerja yang leluasa untuk bergerak. Kondisi kelas serbaguna yang memerlukan pengaturan ruang saat akan digunakan praktik mata kuliah tertentu mengharuskan mahasiswa menggeser meja dan kursi agar ruangan lebih luas.

Pada observasi penggunaan alat mekanik dan alat listrik, sebagian kecil mahasiswa belum menggunakan gunting 
pangkas dan razor sesuai dengan fungsinya. Tidak memegang gunting dan razor sesuai dengan standar operasional prosedur berpotensi mencelakai dirinya sendiri dan orang lain, akibat tertusuk gunting, tergores, atau terpotong, terlebih dengan kondisi kelas yang padat. Selain itu ditemukan juga mahasiswa dan dosen yang mengalami kecelakaan kerja berupa kulit tergunting saat melakukan pangkas rambut karena kurang hati-hati dan kurang perhitungan saat memangkas rambut. Tidak melakukan pengecekan kondisi alat sebelum menggunakan alat listrik juga ditemukan saat observasi, hal ini berpotensi menimbulkan gangguan dan kerusakan pada alat, dan sumber listrik.

Pada observasi pengelolaan kosmetik ditemukan sebagian mahasiswa tidak membaca dan mencermati label kosmetik dan mengambil kosmetik secara berlebihan tidak sesuai kebutuhan, serta tidak mengecek kebersihan wadah kosmetik yang digunakan, dan ada mahasiswa mengambil kosmetik dan meletakkan pada wadah sembarangan seperti pada kertas, pada tutup bedak, dan pada tissue. Hal ini jelas tidak sesuai dengan SOP kosmetik. Kondisi ini berpotensi menimbulkan gangguan berupa iritasi, alergi karena penggunaan kosmetik yang tidak sesuai jenis kulit, dan wadah kosmetik yang kurang bersih. Pada ruang lingkup observasi sanitasi hygiene pada alat dan area kerja, ditemukan sebagian kondisi kuas make up yang tidak terjaga kebersihannya, tas kosmetik yang berantakan dan tidak tertata rapi, handuk yang lembab, jas praktik yang terkena noda kosmetik, dan meletakkan kemasan makanan/minuman pada laci meja bukannya pada tempat sampah.

Berdasarkan uraian di atas, diperlukan strategi, motivasi dan pendampingan terus menerus untuk meningkatkan kesadaran mahasiswa, laboran, dan dosen untuk menerapkan K3 dalam kegiatan sehari-hari, khususnya kegiatan praktik di laboratorium tata rias. Untuk membuat standar operasioanal prosedur pada ketiga bidang keahlian tata kecantikan kulit, tata kecantikan rambut dan tata rias pengantin, mengacu pada prosedur kerja praktik masing-masing kompetensi pada ketiga bidang keahlian tersebut, serta mengacu pada pengetahuan dasar, prinsip dan penerapan K3. Temuan-temuan yang diperoleh pada proses dan hasil pengumpulan data akan digunakan sebagai pertimbangan mengambil keputusan menetapkan standar operasional prosedur yang paling tepat, terukur, dan memiliki korelasi langsung dengan praktik tata rias dan kecantikan.

Penetapan SOP yang sesuai dengan prinsip K3 pada masing-masing bidang keahlian diharapkan dapat menumbuhkan kesadaran dan kedisiplinan mahasiswa, dosen, dan laboran yang lebih nyata dalam penerapan K3 selama praktik dan juga dapat meningkatkan kualitas praktik itu sendiri baik dari segi proses dan hasil kerja.

Penetapan SOP yang sesuai dengan prinsip K3 untuk bidang keahlian tata kecantikan kulit dibuat dengan memperhatikan prinsip-prinsip dasar dan kompetensi tata kecantikan kulit. Pada bidang keahlian tata kecantikan kulit terdapat kompetensi rias wajah (make up), perawatan wajah secara manual, perawatan wajah menggunakan alat listrik, SPA, perawatan tubuh secara tradisional, perawatan tubuh menggunakan alat listrik, manicure dan pedicure, serta rias fantasi. Penyusunan SOP dibagi menjadi 2 kategori kelompok kompetensi yaitu kompetensi rias wajah dan kompetensi perawatan wajah dan tubuh.

Penetapan SOP yang sesuai dengan prinsip K3 untuk bidang keahlian tata kecantikan rambut dibuat dengan memperhatikan konsep dasar tata kecantikan rambut, prinsip-prinsip dasar dan kompetensi tata kecantikan kulit. Pada bidang keahlian tata kecantikan rambut terdapat kompetensi pangkas rambut, pengeritingan, pelurusan rambut, pewarnaan rambut, pratata dan styling rambut, sanggul modern serta sanggul daerah dan SOP dibuat menjadi satu.

Standar Operasional Prosedur (SOP) yang sesuai dengan prinsip K3 untuk kegiatan praktik tata rias pengantin dibuat dengan memperhatikan konsep dasar tata rias pengantin, dan jenis-jenis tata rias pengantin dengan kompetensi rias pengantin Indonesia, pengantin Barat, dan Pengantin Muslim.

\section{SIMPULAN}

Berdasarkan data hasil penelitian dan pembahasan di atas, maka dapat disimpulkan sebagai berikut (1) Kesehatan dan Keselamatan Kerja (K3) di lingkungan prodi tata rias baik penerapan pada diri sendiri, alat dan bahan praktik, serta area kerja praktik sudah diterapkan. Mahasiswa, laboran dan 
dosen pengampu memiliki komitmen untuk melakukan K3, memiliki pengetahuan dasar K3, dan bersedia menerapkan K3 sesuai dengan standar operasional prosedur yang berlaku, (2) Standar Operasional Prosedur (SOP) yang sesuai dengan prinsip K3 untuk bidang keahlian tata kecantikan kulit dibuat dengan memperhatikan prinsip-prinsip dasar dan kompetensi tata kecantikan kulit. Penyusunan SOP dibagi menjadi dua kategori kelompok kompetensi yaitu kelompok kompetensi rias wajah dan kelompok kompetensi perawatan wajah dan tubuh. (3) Standar Operasional Prosedur (SOP) yang sesuai dengan prinsip K3 untuk bidang keahlian tata kecantikan rambut dibuat dengan memperhatikan konsep dasar tata kecantikan rambut, prinsip-prinsip dasar dan kompetensi tata kecantikan rambut. Penyusunan SOP dibuat menjadi satu, dan (4) Standar Operasional Prosedur (SOP) yang sesuai dengan prinsip K3 untuk kegiatan praktik tata rias pengantin dibuat dengan memperhatikan konsep dasar tata rias pengantin, dan jenisjenis tata rias pengantin dengan kompetensi rias pengantin Indonesia, pengantin Barat, dan Pengantin Muslim

\section{REFERENSI}

[1] E. Z. Khayati, B. Lastariwati, dan Sugiyono. 2014. Analisis penerapan kesehatan dan keselamatan kerja di $\begin{array}{llll}\text { jurusan } & \text { PTBB }\end{array}$
Penelitian.Fakultas Teknik Universitas Negeri Yogyakarta.

[2] Emy Indaryani. 2003. Sanitasi dan Hygiene Kecantikan. Kementrian pendidikan dan kebudayaan, Direktorat Pembinaan Sekolah Menegah kejuruan.

[3] Herni Kusantati, Pipin Tresna, P. \& Winwin Wiana. 2008. Tata Kecantikan Kulit. Departemen Pendidikan Nasional Direktorat Pembinaan Sekolah Menegah Kejuruan Dirjen Pendidikan Dasar dan Menengah.

[4] Markkanen, Pia. K,. 2004. Keselamatan dan Kesehatan Kerja di Indonesia. International Labour Organization for South-East and the Pacific.Philipines.

[5] Miles, M.B., \& Huberman, A.M., 1992. Analisis Data Kualitatif, Penerjemah: Tjetjep Rohendi Rohidi. Penerbit: Universitas Indonesia Press. Jakarta

[6] Rina Rifqie mariana. 2003. Hygiene, Sanitasi dan K3 pada Salon kecantikan. Kementrian pendidikan dan kebudayaan, Direktorat Pembinaan Sekolah Menegah kejuruan.

[7] Rijal, T, 2015. Makalah K3. www.sanggarkesehatan.com/2015/makala h-kesehatan-dan-keselamatan-kerja.html).

[8] Rostamailis, Hayatunufus, \& Merita Yanita. 2008. Tata kecantikan Rambut Jilid I. Departemen Pendidikan Nasional Direktorat Pembinaan Sekolah Menegah Kejuruan Dirjen Pendidikan Dasar dan Menengah. 